\title{
Sapen Radio and TV Programs as Supporting Media During Covid-19 Distance Learning
}

\author{
Nada Savitri Nawangsari*, Ali Mustadi, Albi Anggito, Astri Widyasari \\ Faculty of Education, Yogyakarta State University, Special Region of Yogyakarta, Indonesia \\ *Corresponding author. Email: nadasavitri.2020@student.uny.ac.id
}

\begin{abstract}
This study aimed to describe and interpret the use of radio and TV learning media with various interactive programs. This research used a qualitative case study. The research participants were teachers, parents, students, and broadcasting trainers at SD Muhammadiyah Sapen Yogyakarta. Data were obtained through interviews and observations. Data were analyzed using interactive analysis techniques from Miles \& Huberman (2014), namely data condensation, data presentation, and drawing conclusions. The results of the study indicate that the use of audiovisual learning media was suitable to support online learning activities in elementary schools during the pandemic. The more senses involved in learning activities at school, the easier the material is accepted and understood. Covid-19 had forced learning activities carried out from home, thus encouraging teachers and schools to develop innovations in learning activities. Sapen Radio and Sapen-TV were alternative media to support distance learning. The media minimize boredom, increase enthusiasm and interest among students. Learning activities became interactive and communicative because teachers use the media with various programs through radio broadcasts, live streaming, and learning videos that were broadcast through the Sapen-TV YouTube channel, thus, support teaching and learning activities. Therefore, it can be concluded that Sapen-Radio and Sapen-TV programs support remote media learning in the covid-19 pandemic.
\end{abstract}

Keywords: elementary school, learning media, radio, TV

\section{INTRODUCTION}

The Covid 19 pandemic creates a significant impact, including in education. Until the end of 2021, the implementation of teaching and learning activities from home has been conducted for almost two years. This condition forces students and teachers to adapt. Learning media is a much-needed learning source. Media can assist students in their learning processes because it provides a variety of features that can help them understand the materials better. Internet-based media such as WhatsApp, Google-Classroom, GoogleMeet, Zoom, and YouTube impressions became media that are very familiar to be used in learning in this pandemic period [1]. Almost all of the media are included in multimedia learning.

Multimedia is defined as a tool that can create dynamic and interactive presentations; multimedia consists of two categories, namely linear and interactive [2]. In line with Saprudin's [3] opinion, multimedia is combined by at least two input or output media. This medium can be audio (sound, music), animation, video, text, graphics, and images.

The implementation of learning in elementary school should be done in a fun way to increase students' engagement. Learning media becomes one of the factors that can make learning more fun and meaningful. The use and selection of learning media should be adapted to the character of elementary school students. The presence of media in the midst of learning is assumed to be more attractive to students in learning so that learning goals can be achieved. The results of the study say that the learning media is very influential on students' learning outcomes because students will have different experiences in the learning process, in addition to students' ability to understand the subject matter will 
be easier by using media [4]. Motivation in elementary school students when learning using media will be increased. This is evidenced by one study that says that elementary school students will get bored faster and difficult to understand the material when learning is only sourced in books, but if there is a medium of learning as an alternative source, it can increase student learning motivation, especially technology-based media [5]. The medium of learning has several benefits, including generating motivation to increase the attention of students in learning, providing non-monotonous learning activities, optimizing the function of all senses, bringing the world closer to the reality that is difficult to obtain in other ways, increasing the possibility of interaction between students and their environment (e.g., through experiments, recordings), increase uniformity in observation, and present learning information consistently and can be repeated or stored as needed [6].

Procurement of a learning medium at the elementary school level is necessary. Learning media is one way to facilitate the learning abilities of elementary school students at a concrete operational stage. According to Piaget, elementary school students are mature enough to use logical thinking, but only for existing physical objects [7]; thus, help is still needed to understand elementary school students, one of which is using learning media. The concept of cognitive learning, according to Piaget, is divided into three, namely active learning, learning through social interaction, and learning through one's own experience [8]. The current conditions are certainly less ideal for carrying out direct learning, creating active learning, then social interaction, and learning through experience is considered less than optimal for now. This is one of the challenges faced by educators in elementary schools because at this stage. It is appropriate to build students' emotional, intellectual, spiritual, and social intelligence. Teachers are the spearhead in primary education [9], so teachers as learning designers need to understand very well the characteristics of their students and everything needed by students, especially in learning activities, in order for learning to be meaningful [10].

Today, technology improves various strategies in various fields, including education [11]. The technology used in the medium of learning, then the basis is audiovisual. Educators can apply audiovisual media technology at all levels of education and disciplines, the point, of course, to convey knowledge by providing sensory stimulation [12]. The statement is also in line with Asri's opinion that audio visual-based learning media can make it easier for students to understand the material taught in the learning process. This is because audio visual-based media can be inserted interesting materials[13]. Muhammadiyah Sapen Elementary
School is one of the private schools in Yogyakarta that developed a learning medium to support the learning process in the pandemic period. Media that are developed are in the forms of radio and TV media. These two media are integrated with audio-visual technology. A study in Pakistan, reviewing educational TV that aired in homes, wrote that this educational TV is very useful for distance learning although the challenge is a one-way model of communication this is met with teachers as performers who give questions during lessons then students will answer via text message [14]

Radio and television in the classification of media are included in electronic media. Radio is a medium that can be used as a source of learning, educational radio broadcasts are not only aimed at parties in the world of education, but anyone can listen to it. Based on radio broadcast literature has many advantages if used as a learning medium, this is because the learning materials that are broadcast and designed have been tailored to the needs of students as their main target, continued by teachers, as well as the education observer community, provide a real learning experience, provide accurate information, and can help solve problems [15]. Radio developed as an educational radio certainly has its own values, including providing news or information that is up to date, attracting interest, having a wide range, and has recreative value in broadcast programs [16]. Television media is audio-visual media with positive influences, including making users more communicative, imaginative, and active [17]. This opinion is a form of support for learning media development in the form of radio and television.

Based on the description above, the learning media development conducted by Muhammadiyah Sapen Elementary School becomes a special attraction to be studied more deeply. The equivalent of elementary school level developing a medium in the form of radio and television is something that is very interesting. Another study entitled "Implementation of Information and Communication Technology-Based Learning Media in Distance Learning," written by Mushfi, in the study obtained results related to the implementation of technology-based learning media that the learning process with the help of information and communication technology is not only applied limited by space, location, or level of education but can be done in various places and involve many people. Technologybased media can be used in distance learning in the forms of computers, television, radio, internet, voice recording, and VCD cassettes [18]. The research has similarities with research that has been done, namely radio and television media for distance learning. School readiness in adjusting existing conditions requires support from parents to maximize the use of this media. 
Therefore, this study aimed to examine the role of Sapen-Radio and Sapen-TV media and various programs in it as a media to support distance learning at Muhammadiyah Sapen Yogyakarta Elementary School during the covid-19 pandemic.

\section{RESEARCH METHODS}

This research used a qualitative approach, and the type was a case study to describe and interpret the school's innovation in depth. The description was carried out in accordance with the real situation related to the school's innovation in the learning process. The research was conducted at Muhammadiyah Sapen Elementary School Yogyakarta on the implementation of learning using Sapen-Radio and Sapen-TV media. Subjects in the study were determined using purposive sampling techniques based on certain criteria and considerations to obtain more effective information. The research subject consisted of classroom teachers, The Head of the School's Badan Penelitian dan Pengembangan, the broadcasting trainer, parents, and students. Data collection was done with interviews, observations, and literature studies. The validity of data was obtained by using the triangulation technique, which was to check and compare the data obtained. The acquisition of data from interview results had similarities with those from observation and literature studies. The data was then analyzed with an interactive model following the format of Miles \& Huberman [19], namely data condensation, data presentation, and drawing conclusions.

\section{RESULT AND DISCUSSION}

Sapen-Radio and Sapen-TV were two forms of audio and audiovisual media developed by Muhammadiyah Sapen Elementary School as supporting media in the implementation of learning activities during The Covid-19. This media was one of the facilities provided by the school. The Head of the School's Badan Penelitian dan Pengembangan of Muhammadiyah Sapen Elementary School said that Sapen-Radio and Sapen-TV were historically established as media to develop creativity and talent for teachers, employees, and students, especially in broadcasting. The unexpected arrival of The Covid-19 changed the two media as alternative distance learning media. The school also prepared various broadcast programs on Sapen-Radio and Sapen-TV. The programs that had been prepared were adjusted to activities that were usually carried out when schools were offline or before the pandemic. The school also provided opportunities for students to develop their talent through Sapen-Radio and Sapen-TV.

"Through collaboration between the fields of education and teaching as well as the fields of research and development, Sapen-Radio and SapenTV will provide an interactive and communicative learning model. The teacher uses these two media through radio broadcast programs, live streaming, and learning videos through the Sapen-TV Youtube channel," continued Mr I.

Radio media was accessed online, while TV media was broadcasted on the school's Youtube channel. The use of the radio made it easier for the listeners to listen to the radio broadcasts anywhere and anytime. Community radio-based blended learning utilized radio networks for learning activities [20]. The implementation of learning through this media could be carried out by collaborating between radio and teachers, with students, and parents. The learning created through this media was blended learning, where teachers and students could still learn the material using technology. The radio was the technology, while the teacher was the facilitator who guided students during learning activities. Like radio in general, Sapen-Radio was arranged with an open and dialogical concept so that students could have the opportunity to express their opinions through the interactive telephone service provided.

Another effort done by the school in honing the teachers' skills as performers on radio and television was by presenting a special broadcasting institution to provide public speaking training. This effort showed the seriousness and readiness of the school to provide the best service for students so that learning would be delivered optimally. Based on the interview results conducted with $\mathrm{Z}$ as the broadcasting trainer, it was found that the innovations made by the school by developing radio and television media were intriguing. The teachers were asked personally to practice then the trainer corrected them directly. Then, the teachers were guided to make a program with their own characteristics.

"During the training process, both young and old teachers show high enthusiasm in learning public speaking. The forms of training include how to become a professional radio broadcaster and a professional presenter, how to organize events or programs, how to insert songs or advertisements, how to open and close a program, how to interact with listeners, and how to operate and synchronize between programs tools used," said Z.

From the parents' point of view regarding the existence of Sapen-Radio and Sapen-TV media, positive responses were obtained. Initially, parents were worried and realized that learning activities carried out from home were new and challenging in the world of education. This concern was in line with a study that described the challenges of distance learning, including 
the lack of interaction, the tendency to ignore academic and social aspects, accuracy and discipline in carrying out assignments, effective use of time, lack of motivation to learn, and the possibility of other learning disorders [21]. The parents believed that Muhammadiyah Sapen Elementary School was ready to implement mature distance learning because they could review the various activities held by the school. An article stated that The Covid-19 condition required educators to carry out online learning since it was found that $90 \%$ of teachers quickly adapt to it [22]. Other than google-meet, zoom, google-classroom, and WA, SapenRadio and Sapen-TV added a variety of online learning activities for students.

"Ideally, the most appropriate learning for children is face-to-face learning because it will play a role in their social development. However, because of the circumstances, audio and visual-based media are suitable for children. They do not experience difficulties and are easy to adapt," said Mrs. N, who became one of the speakers in this study.

The presence of Sapen-Radio and Sapen-TV in the midst of the implementation of learning during The Covid-19 managed to restore the students' spirit and interest in studying. In line with a case study research that stated that radio remains a powerful medium of communication, this was due to the fact that its message content can be received in distant places due to its wide scope and ubiquitous nature. Radio could reach large audiences because it was relatively inexpensive and could function without electricity. Therefore, it was considered the most accessible technological tool used to spread information [23]. The parents could accompany their children learning at home because both media could be accessed by anyone and anywhere. Parents who monitored learning activities through Sapen-Radio and Sapen-TV said that these two media succeeded in minimizing children's boredom with online learning. Mrs. $\mathrm{N}$ said that her child became acquainted with radio and wanted to listen to the radio because of the Sapen-Radio.

Muhammadiyah Sapen Elementary School had a jargon that read "Mengedukasi Tiada Henti" (never stop educating). According to Mrs. L, this jargon was in accordance with the character of the school. This proved the readiness of the school in adapting to emergency conditions, one of which was the innovation of presenting learning media in the form of radio and television. This effort was considered as a form of school readiness as well as teachers in facilitating students so that they could continue to have fun learning from home. In addition to these two media, the teachers also prepared various other media so that students had many choices for learning. Based on the monitoring carried out by parents, the broadcasting programs on
Sapen-Radio and Sapen-TV were considered helpful for children in learning from home in accordance with the jargon that had been carried.

"The programs in Sapen-Radio and Sapen-TV, in addition to presenting subject matter content, also provide entertainment that has moral values such as reading the Koran in the morning, fairy tales, songs, and many more. Of course, this is excellent for children because it can be a fun distraction in the middle of schoolwork," continued Mrs. L, who was also a resource person in this research.

In addition to providing academic facilities, these two media were also a forum for students who wanted to publish their work, such as poetry, video blogs, or other content. This certainly attracted students' interest to keep working even if only from home. This effort was a form of appreciation made by the school for creative children. It was expected that other students would also be interested in making other works. Mrs. L hoped that the Sapen-Radio and Sapen-TV media would continue to exist even after the pandemic ended. There was an additional program proposed by Mrs. L for Sapen-Radio and Sapen-TV, namely a mini-research program for students so that students could do fun and useful activities at home outside of learning activities.

The monitoring results on learning activities using the media Sapen-Radio and Sapen-TV showed that the students looked enthusiastic. For example, when TV showed on the YouTube channel of Muhammadiyah Sapen Elementary School broadcast about sports material, namely gymnastics, then students were in front of the television watching the program and imitating the movements made by the teacher. Another observation was made when students used radio media in mathematics, the teacher's voice was heard giving questions and then students worked on their notebooks. Another material while learning Javanese traditional songs was when the teacher opened an interactive telephone service. There was one student who was connected by telephone and then tried to sing the traditional song with the help of the teacher. Based on the results of this monitoring, it was clear that there was enthusiasm from the students in participating in learning. According to parents, students were enthusiastic when lessons were delivered directly by the teachers themselves, not using other people's learning videos. Through Sapen-Radio and Sapen-TV, at least students could recognize the teachers. Teachers even though they have not met in person. Parents had high hopes that Sapen-Radio and Sapen-TV would always be learning media for students even though learning will return to normal in the future.

Based on the results obtained from the interview process, observation, and literature review, technology 
in education had a big role. The benefits could be felt when there was good collaboration between schools, parents, and students themselves. The use of radio and television as learning media were in accordance with the characteristics of elementary school-aged students who were easier to learn from what they saw and heard. Their understanding of something will improve when the child listens to the material [24]. Technology in the implementation of learning activities is very important and can be useful for welcoming more effective education in the future [25]. The use of media such as radio and television certainly required the skills of its users. The innovations made by Muhammadiyah Sapen Elementary School show that all school components sought to take advantage of technological developments as an opportunity to manage digital content well so that it could be used as a supporting medium when implementing distance learning [26].

\section{CONCLUSION}

The development of media to support teaching and learning activities, especially during online learning, is required. An example of media developed in Muhammadiyah Sapen Elementary School media is radio and television. Both these media present various programs, both academic and non-academic. The school supports these by providing public speaking training for teachers. Students enthusiastically and passionately in engaging with the tv and radio broadcasts. Therefore, Sapen-Radio and Sapen-TV programs are considered valuable to support remote media learning during the COVID-19 pandemic.

\section{ACKNOWLEDGMENTS}

Acknowledgments are conveyed to the students and lecturer of Elementary Education Program, Faculty of Education, Yogyakarta State University who give motivation and facilities, and also to the teachers, parents, and students in Muhammadiyah Sapen Yogyakarta Elementary School in Yogyakarta, Indonesia as the subjects of this research.

\section{REFERENCES}

[1] I. Kartini, E. Rohaeti, and S. Fatimah, "Gambaran Motivasi Belajar Peserta Didik Saat Pandemi Covid 19 (Studi Kasus pada Peserta Didik Kelas VII SMP N 1 Arjasari yang sedang Belajar dari Rumah karena Pandemi Covid 19)," Fokus (Kajian Bimbing. dan Konseling dalam Pendidikan), 2020, vol. 3, no. 4, pp. 140-150.

[2] P. Manurung, "Multimedia Interaktif Sebagai Media Pembelajaran Pada Masa Pandemi Covid 19," Al-Fikru J. Ilm., vol. 14, no. 1, 2021, pp. 1-12 , DOI: 10.51672/alfikru.v14i1.33.

[3] S. Saprudin, M. Munaldi, A. Wijoyo, and M.
Prasetio, S, "Pembelajaran Multimedia (Studi Kasus: SMK Indonesia Global)," Jamaika J. Abdi Masy., vol. 1, no. 1, 2020, pp. 63-70.

[4] R. Wahyuningtyas and B. S. Sulasmono, "Pentingnya Media dalam Pembelajaran Guna Meningkatkan Hasil Belajar di Sekolah Dasar," EDUKATIF J. Ilmu Pendidik., vol. 2, no. 1, 2020, pp. 23-27, [Online]. Available: https://edukatif.org/index.php/edukatif/index.

[5] Y. D. Puspitarini and M. Hanif, "Using Learning Media to Increase Learning Motivation in Elementary School," Anatol. J. Educ., vol. 4, no. 2, 2019, pp. 53-60, DOI: 10.29333/aje.2019.426a.

[6] A. Muhson, "Pengembangan Media Pembelajaran Berbasis Teknologi Informasi," J. Pendidik. Akunt. Indones., vol. 8, no. 2, 2010, DOI: 10.21831/jpai.v8i2.949.

[7] R. A. Juwantara, "Analisis Teori Perkembangan Kognitif Piaget pada Tahap Anak Usia Operasional Konkret 7-12 Tahun dalam Pembelajaran Matematika," Al-Adzka J. Ilm. Pendidik. Guru Madrasah Ibtidaiyah, vol. 9, no. 1, 2019, p. 27, DOI: 10.18592/aladzkapgmi.v9i1.3011.

[8] F. Mashudi, Psikologi Konseling Buku Panduang Lengkap dan Praktis Menerapkan Psikologi Konseling, 2013, Yogyakarta: Ircisod.

[9] Y. Auliaty and T. Sekaringtyas, "Workshop Pengembangan Kecerdasan Interpersonal dengan Menggunakan Model React di Sekolah Dasar Negeri Kecamatan Ciputat Tangerang Selatan Banten," 2019, [Online]. Available: http://journal.pgsdfipunj.com/index.php/prosidingpengabdian/article/view/149.

[10] N. Septianti and R. Afiani, "Pentingnya Memahami Karakteristik Siswa Sekolah Dasar di SDN Cikokol 2," As-Sabiqun, vol. 2, no. 1, 2020, pp. 7-17, DOI: 10.36088/assabiqun.v2i1.611.

[11] R. Komalasari, "Manfaat Teknologi Informasi dan Komunikasi di Masa Pandemi Covid 19," J. Teknol. Inf. dan Komun., vol. 7, no. 1, 2020, pp. 38-49.

[12] C. Nicolaou, M. Matsiola, and G. Kalliris, "Technology-enhanced learning and teaching methodologies through audiovisual media," Educ. Sci., vol. 9, no. 3, 2019, DOI: 10.3390/educsci9030196.

[13] B. Asri, K. Nurhalim, and P. Suhandini, "The Implementation of Talking Stick Model Assisted by Audiovisual Media Toward Positive Character and Learning Outcome," J. Prim. Educ., vol. 8, no. 2, 2019, pp. 225-231. DOI: https://doi.org/10.15294/jpe.v8i2.26487. 
[14] S. Zacharia, "Pakistan: TeleSchool and Taleem Ghar (Educational TV at Home)," 2020, [Online]. Available: http://documents1.worldbank.org/curated/en/42182 1600058352361/pdf/Pakistan-TeleSchool-andTaleem-Ghar-Educational-TV-at-Home.pdf.

[15] M. Srikandini, E. Afgani, and E. Pitoy, "Radio Gema Edukasi Streaming as A Learning Resource: A Literatur Review," Int. J. Res. Publ., vol. 78, no. 1, 2021, pp. 12-17, DOI: 10.47119/IJRP100781620211979.

[16] N. Innayah and M. Susanti, "The Role of The Listener and Government Institutions in Educational Radio Broadcasts (Peran Serta Pendengar dan Lembaga Pemerintah dalam Siaran Radio Pendidikan)," J. Pekommas, vol. 1, no. 1, 2016, p. 21, DOI: 10.30818/jpkm.2016.2010103.

[17] G. Rohani, "Pengaruh Televisi (TV) terhadap Aspek-Aspek Perkembangan Anak Usia 3-4 Tahun,” J. Pendidik. Anak, 2015, vol. 4, no. 2.

[18] M. Mushfi, "Implementasi Media Pembelajaran Berbasis Teknologi Informasi dan Komunikasi dalam Distance Learning," J. Tarbiyatuna Kaji. Pendidik. Islam, vol. 3, no. 1, 2019, pp. 29-40, DOI:

https://doi.org/10.29062/tarbiyatuna.v3i1.198.

[19] M. B. A. Miles and M. Huberman, Analisis Data Kualitatif. Jakarta: UI Press, 2014.

[20] R. C. I. Prahmana, D. Hartanto, D. A. Kusumaningtyas, R. M. Ali, and Muchlas, "Community radio-based blended learning model: A promising learning model in remote area during pandemic era," Heliyon, vol. 7, no. 7, p. e07511, 2021, DOI: 10.1016/j.heliyon.2021.e07511.

[21] A. Kahfi, "Tantangan Dan Harapan Pembelajaran Jarak Jauh Di Masa Pandemi Covid 19," Dirasah, vol. 03, no. 2, 2020, pp. 137-154, [Online]. Available: https://stai-binamadani.ejournal.id/jurdir.

[22] L. A. Alea, M. F. Fabrea, R. D. A. Roldan, and A. Z. Farooqi, “Teachers' Covid-19 awareness, distance learning education experiences and perceptions towards institutional readiness and challenges," Int. J. Learn. Teach. Educ. Res., vol. 19, no. 6, 2020, pp. 127-144, DOI: 10.26803/ijlter.19.6.8.

[23] A. Okeke, J. Nwosu, and G. Ono, "Use of Radio as a Tool of Learning in Crisis Period," J. Commun. Media Stud., vol. 1, no. 2, 2020, pp. 1-11, DOI: http://dx.doi.org/10.47851/naujocommed.v1i2.95.

[24] K. Allen and R. Lynn, Profil Perkembangan Anak Pra Kelahiran Hingga Usia 12 Tahun. Jakarta: PT Indeks, 2010.
[25] R. Rahmi, "Inovasi Pembelajaran di Masa Pandemi Covid-19," Al-Tarbiyah J. Pendidik. ( Educ. J. ), vol. 30, no. 2, 2020, pp. 111-123. DOI: 10.24235/ath.v.

[26] M. Hamid et al., Media Pembelajaran, 1st ed. Medan: Yayasan Kita Menulis, 2020. 